Şen, Ü. (2016). İki dilli Türk çocuklarına Türkçe öğretiminde öğretmen yetiştirme sorunu ve üniversitelerdeki mevcut durumun değerlendirilmesi. Ana Dili Eğitimi Dergisi, 4(4), 518-529.

\begin{tabular}{c}
$\begin{array}{c}\text { Ana Dili Eğitimi Dergisi } \\
\text { Journal of Mother Tongue Education } \\
\text { www.anadiliegitimi.com }\end{array}$ \\
Geliş/Received: $26.08 .2016 \quad$ Kabul/Accepted:03.10.2016 \\
\hline
\end{tabular}

\title{
İki Dilli Türk Çocuklarına Türkçe Öğretiminde Öğretmen Yetiştirme Sorunu ve Üniversitelerdeki Mevcut Durumun Değerlendirilmesi
}

\begin{abstract}
Ülker ŞEN ${ }^{1}$
Öz

Yurt dışına 1960'larda başlayan Türk işçi göçü ile özellikle Avrupa ülkelerinde olmak üzere birçok ülkede dört milyonu aşkın bir Türk nüfusu oluşmuştur. Bu nüfusun Türkiye ile olan en güçlü bağı Türkçedir. Türkçe bağının devamı, sağlamlığı için öncelikle aile içinde Türkçe konuşulmalı ikinci aşamada ise iki dilli Türk çocuklarına Türkçe öğretimi yapılmalıdır. İki dilli Türk çocuklarına Türkçe öğretiminin kaliteli ve etkili bir şekilde yapılabilmesinin yolu, alana yönelik donanımlı öğretmen yetiştirmekten geçmektedir. Bu çerçeveden konuya baktığımızda "Türkiye'de iki dilli Türk çocuklarına Türkçe öğretmek için öğretmen yetiştirilmekte midir?" sorusunun cevabının önemli olduğu görülmüştür. Bu çalışmanın amacı i ki dilli Türk çocuklarına Türkçe öğretiminde öğretmen yetiştirme kapsamında lisans ve lisansüstü programlarını ihtiyacı karşılama ve içerik açısından değerlendirmektir. Çalışma tarama modelinde ol up veriler doküman ta ra ma yolu ile el de edilmiştir. Elde edilen veriler içerik analizi ile analiz edilmiştir. Çalışmanın en önemli sonucu iki dilli Türk çocuklarına Türkçe öğretimi alanında bir öğretmen yetiştirme programının ol madı̆ı̆ıır. İki dilli Türk çocuklarına Türkçe öğretimi alanında uzman yetiştiren bir yüks ek lisans programının olduğu, doktora programının ise olmadığı diğer dikkate değer sonuçlardır.
\end{abstract}

Anahtar Kelimeler: İki dilli Türk çocukları, Türkçe öğretimi, Türkçe ve Türk Kültürü dersi, Öğretmen yetiştirme, Lisans ve lisansüstü programlar

\section{The Problem of Teacher Education in Teaching Turkish to Bilingual Turkish Children and an Evaluation of the Current Situation in Universities}

\begin{abstract}
Starting with the Turkish worker immigration which began in the 1960s, a population of more than four million Turkish people has come into existence in many countries, especially in European countries. Turkish is the most powerful bond between this immigrant population and Turkey. For the continuation and strengthening of this bond, the first thing to do is to speak Turkish in the family, and in the second stage Turkish education should be given to bilingual Turkish children. In order for high quality and effective teaching of Turkish to bilingual Turkish children, well-equipped teachers should be trained. Looking at the issue from this perspective, the answer to the question, "Are teachers trained in Turkey in order to teach Turkish to bilingual Turkish children?" seems to be important. The main aim of this study is to evaluate undergraduate and graduate Turkish teacher training programs for teaching Turkish to bilingual Turkish children in terms of the programs' satisfying the demand and the relevance of their content. The study uses survey research design and the data were obtained through document survey. The obtained data were analyzed, using content analysis. The most important result of the study is that there is not a teacher training program for teaching Turkish to bilingual Turkish children. That there is a Master's program which trains specialists in the field of teaching Turkish to bilingual Turkish children, but that there is not a doctoral program in the field are other notable results.
\end{abstract}

Key Words: Bilingual Turkish children, teaching Turkish, Turkish and Turkish Culture course, Teacher education, Undergraduate and graduate programs.

\footnotetext{
${ }^{1}$ Dr. Gazi Üniversitesi, Gazi Eğitim Fakültesi, E-Posta:ulker_sen@hotmail.com
} 
İki Dilli Türk Çocuklarına Türkçe Öğretiminde Öğretmen Yetiştirme Sorunu Ve Üniversitelerdeki Mevcut Durumun Değerlendirilmesi

\section{Giriş}

İki dilli Türk çocuklarının büyük bir çoğunluğu Avrupa ülkelerinde yaşamaktadır. Bu çocuklar, yaşadıkları ülkelerde bir yandan topluma uyum sağlamak, toplumda yer edinmek, eğitimalmak, meslek sahibi olmak vb. için toplum dilini öğrenip kullanırlarken diğer yandan aile bireyleri ile bağlarını ve iletişimlerini sürdürmek, Türkiye'deki akrabalarıile anlaşabilmek, kültürlerini yaşatabilmekvb. için ana dillerini öğrenmekteve kullanmaktadırlar. İki dilli olma durumu yakın zamanlara kadar eksiklik, zayıflık, yetersizlik, aidiyetsizlik gibi olumsuz kavramlarla birlikte kullanılmıştır. Ancak son zamanlarda yapılan çalışmalarla iki dilliliğin bir zenginlik olduğu, ana dilinin öğrenilmesi ve yaşatılmasının iki dillilik için önemli olduğu ortaya konmuştur (Cummins, 2001: 17). íki dilli bireylerin toplum dilini etkili bir şekilde öğrenip kullanmaları, yaşadıkları toplumla uyumlu ve barışık olmalarının yolu ana dili eğitiminden geçmektedir denilebilir. Bu durum göz önüne alındığında iki dilli Türk çocukların ın ana dillerini en iyi şekilde öğrenmelerinin gerekliliği kendiliğinden ortaya çıkmaktadır.

İki dilli Türk çocukları ana dillerini öncelikle ailelerinden ve yakın çevrelerinden edinmektedir. İki dilli Türk çocuklarının, edindikleri bu dili kullanırken Türkçenin kuralları, telaffuzu, yazımı vs. açısından birtakım yanlışlıklar yaptıkları görülebilmektedir. Örneğin;

"- Seni pausede Schulplatzda bekliyom! (Seni teneffüste okulun bahçesinde bekliyorum.)

- Krank almak için doktora gidiyom! (Hastalık raporu almak için doktora gidiyorum.)

- Heute okula gitmek için kein lust! (Bugün okula gitme isteğim yok.)

- Kindergartendan çocuğumu abholen yapacam! (Anaokulundan çocuğumu alacağım.)" (akt. Koçak, 2012: 309) gibi ikinci dilinden sözcük alımı hatalarına yurt dışında yaşayan Türk çocuklarında sıklıkla rastlanmaktadır.

Konuşma beceri alanında olduğu gibi yazma beceri alanında da buna benzer sorunlara görülmektedir. Aşağıda Almanya'da yaşayan iki dilli bir Türk çocuğuna ait metin yer almaktadır. Metinde görüleceği üzere konuşmada olduğu gibi ikinci dilden sözcük alımı/kullanımı hatalan yapılmıştır.

"Dün Babamla Annemle Feste gidik. Reisenrad bindik. Babam bise popcorn aldı. Taumler bindim. Zuckerwatte yidik. Mandeln yidim. Gezdik. Autosguta bindim. Babam'da bindi. Annem'de popcorn yedi. Teigecet bindim. Schokoladeneis yidik. Ve bide Riesenrada bindim. Elmaşekeri yedim. Waschmaschine bindim (Aytemiz, 2000: 94).

İki dilli Türk çocuklarının yazılı anlatımlarında ikinci dilin etkisinden kaynaklanan yazım yanlışları, anlatım bozuklukları olduğu gibi yazı yazma teknikleri açısından (harf uzantıları, harf boyları, 
gibi) da Türkçenin kurallarına uygunyazamamaktan kaynaklanan sorunlar da ayrıca üzerinde durulması gereken bir konudur.

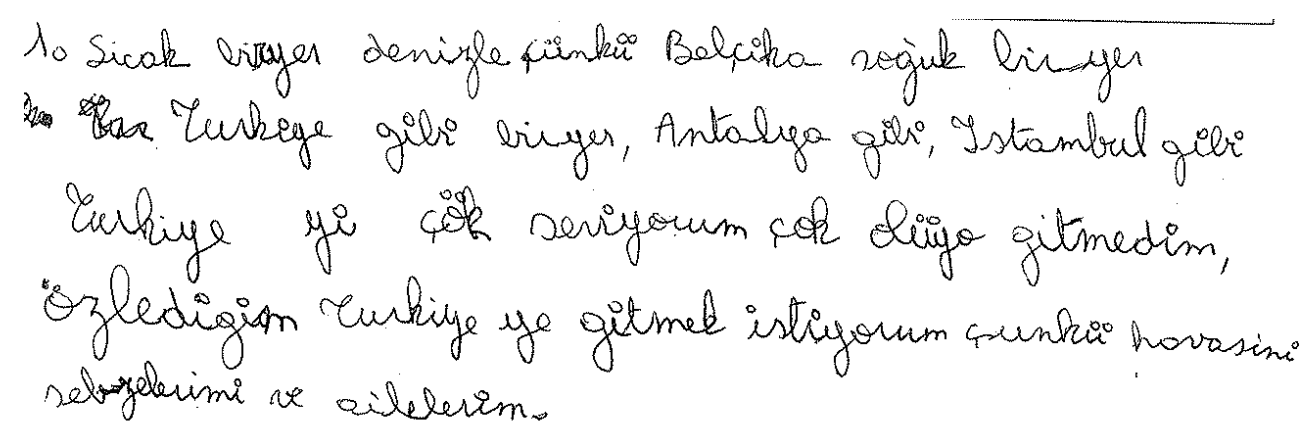

Yukarıda Belçika'da yaşayan iki dilli bir Türk çocuğunun yazılı anlatımı bulunmaktadır. Bu metinde yazım yanlışı, noktalama işaretinin yanlış kullanımı, cümle dizilimi gibi hatalar ilk başta göze çarpmakta, ayrıca yazı yazma teknikleri açısından da birçok hata bulunmaktadır.

İki dilli Türk çocuklarının ana dillerinde yaşadıkları sorunların tespitine ve çözümüne yönelik yapılan çalışmalar her geçen gün artmaktadır. Yapılan bu çalışmalarda iki dilli Türk çocuklarının ana dillerinde oluşturdukları yazılı anlatımlarda hata yaptıkları (ikinci dilden kelime alımı, Türkçenin söz dizimine uygun cümleler kuramama, eklerin yanlış kullanımı, ağız özelliklerinin metne yansıtılması, alfabeden kaynaklanan yanlışlarvs.), kendilerini ifade etmede zorlandıkları, yeterli ve etkili bir Türkçe eğitimi alamadıkları (Belet, 2009; Cengiz ve Türk 2009; Sarı, 2001; İnce, 2011; Şen, 2011; Yıldı, 2012; Yıldız ve Öztürk 2013) tespit edilmiştir.

Çalışmalardan elde edilen verilere göre iki dilli Türk çocu klarının Türkçeyi doğru, etkili ve istekle kullanabilmeleri için düzenli, sistemli ve ciddi bir ana dili eğitimi gereklidir. Yurt dışında yaşayan Türk çocuklarının ana dili eğitimleri ülkelere göre değişiklik gösterebilmektedir. Bazı ülkelerde iki dilli Türk çocuklarının Türkçe eğitimleri yerel yönetimlerin sorumluluğunda olduğu gibi bazı ülkelerde bu sorumluluk Türkiye Cumhuriyeti'ne verilmiştir. Türkiye'de örgün eğitim kurumlarında Türkçenin öğretimi devletin sorumlul uğunda ve denetimindedir. Bu sorumluluk aynı şekilde yurt dışındaki Türk vatandaşları için de geçerlidir. Anayasanın 62. maddesinde "Devlet, yabancı ülkelerde çalışan Türk vatandaşlarının aile birliğinin, çocuklarının eğitiminin, kültürel ihtiyaçlarının ve sosyal güvenliklerinin sağlanması, anavatanla bağlarının korunması ve yurda dönüşlerinde yardımcı olunması için gereken tedbirleri alır." ifadesi bunun bir göstergesidir.

Yurt dışındaki vatandaşların Türkçeyi doğru, etkili ve güzel kullanmasını sağlamak için devlet bünyesinde birtakım kurumlarca çeşitli faaliyetler yapılmaktadır (Demir, 2016). Ancak bunlar içinde belki de en önemlisi Millî Eğitim Bakanlığının denetiminde ve sorumluluğunda yurt dışında Türkçe ve 
İki Dilli Türk Çocuklarına Türkçe Öğretiminde Öğretmen Yetiştirme Sorunu Ve Üniversitelerdeki Mevcut Durumun Değerlendirilmesi

Türk kültürü dersinin verilmesidir. Derslerin sorumluluğu Türkiye Cumhuriyeti Devleti'nde olduğu için dersi verecek öğretmenler de Türkiye'den gönderilmektedir.

Millî Eğitim Bakanlığı senede ortalama 400 öğretmeni yurt dışında Türkçe ve Türk kültürü derslerini vermek üzere görevlendirmektedir. Türkçe ve Türk kültürü dersleri için yapılan görevlendirmelerde alan uzmanlığı, alan eğitimi gibi şartlar aranmadan genel olarak meslekte 5 yılını tamamlamış, herhangi bir yabancı dilden 50 puan (yabancı dil seviye tespit sınavı veya eşdeğer bir sınavdan) almış, Mesleki Yeterlilik Sınavını ve Temsil Yeteneği Mülakatını geçmiş öğretmenler görevlendirilebilmektedir. Öğretmen görevlendirmelerinin daha titiz yapılması beklenirken Millî Eğitim Bakanlığı, 2016 yılı yurt dışı görevlendirmelerinde Mesleki Yeterlilik Sınavını kaldırmış, öğretmenler sadece Temsil Yeteneği Mülakatı ile seçilmiştir.

Öğretmen görevlendirmelerine ilişkin eleştirilerden biri de Mesleki Yeterlilik Sınavının Atatürk İlkeleri ve T.C. İnkılâp Tarihi, Türk Tarihi, Türk Kültür ve Medeniyeti, Türkiye Coğrafyası, Vatandaşlık Bilgileri vb. konularını kapsamasıdır. Burada eleştirilen nokta, başta Avrupa ülkeleri olmak üzere görevlendirmenin yapılacağı ülkelerle ilgili konuların (ülkelerin eğitim sistemi, ekonomisi, tarihi, vb.) sınav kapsamına alınmaması, dolayısıyla sınavda öğretmenlere bu konulara ilişkin soruların sorulmamasıdır (Aydoğan, 2008).

2015 yılı öğretmen görevlendirmelerine göre (DiGM, 2015) Almanca konuşulan ülkelerde Türkçe ve Türk kültürü dersi vermek üzere Türkçe, Türk Dili ve Edebiyatı, Almanca, Sınıf Öğretmeni, Sosyal Bilgiler, Din Kültürü ve Ahlak Bilgisi, Okul Öncesi, Rehberlik, Beden Eğitimi, Sınıf Öğretmeni (Resmîkurumlardan alınmış Halk Oyunları Usta Öğreticilik Belgesiolanlar), Müzik branşlarında toplam 198 öğretmen görevlendirilmiştir.

Fransızca konuşulan ülkelerde Türkçe ve Türk kültürü dersi vermek üzere Türkçe, Türk Dili ve Edebiyatı, Fransızca, Sınıf Öğretmeni, Sosyal Bilgiler, Din Kültürüve Ahlak Bilgisi, Rehberlik branşlarında toplam 64 öğretmen görevlendirilmiştir.

İngilizce ve diğer dillerin konuşulduğu ülkelerde Türkçe ve Türk kültürü dersi vermek üzere İngilizce, Sınıf Öğretmeni, Türkçe, Türk Dili ve Edebiyatı, Din Kültürü ve Ahlak Bilgisi, Matematik branşlarında toplam 167 öğretmen görevlendirilmiştir.

Görevlendirilen branşlara bakıldığında Türkçe ve Türk Kültürü dersini "Din Kültürü ve Ahlak Bilgisi Öğretmeni" de "Sosyal Bilgiler Öğretmeni" de "Türkçe Öğretmeni" de verebilmektedir.

Özetle; yurt dışında Türkçe öğretimine ihtiyacı olan iki dilli ve iki kültürlü büyük bir kitle bulunmaktadır. Bu kitle ayrıca iki dilli ve iki kültürlü olmanın getirdiği birtakım sorunlaryaşamaktadır. Dolayısıyla iki dillilikten kaynaklanan sorunların giderilmesi gerekmektedir. Bunun için ana di li öğretim etkinliklerinin hedef kitleye göre düzenlenmesi ve bu etkinlikleri iki dilli Türk çocuklarına göre 
düzenleyecek öğretmenlerin de bu alanda eğitim almış olması gerekmektedir. Alanda yapılmıs çalışmalara bakıldığında (Demirtaş, 2014; Abalı, 2000; Aydoğan, 2008) iki dilli Türk çocuklarına Türkçe öğretimi alanında yetişmiş öğretmen ihtiyacının bulunduğu, öğretmenlerin bu konuda önemli bir yere sahip olduğu, yurt dışına görevlendirilen öğretmenlerin seçimlerinde sıkıntılar yaşandığı, eğitim sürecinde öğretmenlerin alan bilgisinin olmamasından kaynaklanan bazı sorunlar yaşandığı gündeme getirilmiştir. Tespitlerden ve elde edilen bilgilerden hareketle bu çalışmanın ana amacı iki dilli Türk çocuklarına Türkçe öğretiminde öğretmen yetiştirme sorunlarını ortaya koymak, ortaya çıkan sorunlar çerçevesinde Türkçe eğitimi çatısı altında yer alan lisans ve lisansüstü programlarını ihtiyacı karşılama ve içerik açııından değerlendirmektir. Bu doğrultuda çalışmanın soru cümleleri şunlardır:

1. Türkçe eğitimi, öğretimi alanında öğretmen yetiştiren lisans programlarınelerdir? Bu lisans programları içinde iki dilli Türk çocuklarına Türkçe öğretimi alanında öğretmen yetiştiren lisans programı bulunmakta mıdır? Varsa programın içeriği nedir?

2. Türkçe eğitimi, öğretimi alanında uzman yetiştiren yüksek lisans programları nelerdir? Bu yüksek lisans programları içinde iki dilli Türk çocuklarına Türkçe öğretimi alanında uzman yetiştiren yüksek lisans programı bulunmakta mıdır? Varsa programın içeriği nedir?

3. Türkçe eğitimi, öğretimi alanında uzman yetiştiren doktora programlarınelerdir? Bu doktora programları içinde iki dilli Türk çocuklarına Türkçe öğretimi alanında uzman yetiştiren doktora programı bulunmakta mıdır? Varsa programın içeriği nedir?

\section{Yöntem}

Bu araştırmada betimsel tarama yöntemi kullanılmıştır. Tarama yöntemi, hâlihazırda mevcut olan veya geçmişte olmuş bir durumu olduğu şekliyle betimleyen bir çal ışma yöntemidir (Karasar 2008). Veriler, doküman taraması yoluyla elde edilmiştir. Araştırma verilerinin toplanması amacıyla öncelikle literatür taraması yapılmış ve kuramsal bölüm oluşturulmuştur. Lisans, yüksek lisans ve doktora programlarının tespiti için internet ortamında tarama yapılmışır. Lisans programlarının belirlenmesinde Yükseköğretim Kurulunun internet sayfasındaki Yükseköğretim Program Atlası kullanılmıştır. Lisansüstü programlarının tespitinde ise yine Yükseköğretim Kurulunun intemet sayfasında ilan ettiği üniversiteler listesi esas alınmıştır. Çalışma, Türkçe eğitimi, öğretimi odağında olduğu için Türkçe öğretimi alanındaki lisans, lisansüstü programları ve bu programlara ait resmî internet sitelerinden ulaşılabilen ders bilgi paketleri ve Türkiye'deki devlet üniversiteleri ile sınırlı tutulmuştur. (Vakıf üniversitelerinin doğrudan devlete bağlı olmayışı, ticari amaç gütmeleri, esnek programlarııı olması çalışmanın devlet üniversiteleriile sınırlandırılmasında etkili olmuştur.) Verilerin analizinde betimsel analizden yararlanılmıştır. Betimsel analizde elde edilen veriler, daha önceden belirlenen başlıklar altında özetlenir ve yorumlanır (Altunışık, vd. 2010). Betimsel analize uygun olarak 
İki Dilli Türk Çocuklarına Türkçe Öğretiminde Öğretmen Yetiştirme Sorunu Ve Üniversitelerdeki Mevcut Durumun Değerlendirilmesi

öncelikle konu ile ilgili bir çerçeve oluşturulmuştur, çerçeveye uygun kavramlar belirlenmiştir, kavramlar tanımlanmış ve son olarak kavramların kullanım durumları yorumlanmıştır.

\section{Bulgular}

Türkçe eğitimi, öğretimi alanında öğretmen yetiştiren lisans programları nelerdir? Bu lisans programları içinde iki dilli Türk çocuklarına Türkçe öğretimi alanında öğretmen yetiştiren lisans programı bulunmakta mıdır? Varsa programın içeriği nedir?

Türkiye'de doğrudan Türkçe eğitimi, öğretimi alanına öğretmen yetiştiren lisans programı Türkçe Öğretmenliği lisans programıdır. Türkiye'de 109 devlet üniversitesinde 1179 fakülte, 14154 bölüm, 24599 ana bilim dalı, 7325 bilim dalı (istatistik.yok.gov.tr/ E.T. 20.05.2016) bulunmaktadır. Yükseköğretim Kurulunun internet sayfasındaki Yükseköğretim Program Atlası aracılı̆̆ı ile Türkiye'de 109 devlet üniversitesinin bünyesinde 63 Türkçe öğretmenliği bölümü tespit edilmiştir. İlgili bölümlerin tamamının ders içerikleri incelenmiştir. İncelemeler sonucunda Gazi Üniversitesi Türkçe Eğitimi Ana Bilim Dalı Türkçe Öğretmenliği programının ders programı hariç diğer üniversitelerin hiçbirinin ders programında iki dilli Türk çocuklarına Türkçe öğretimine yönelik bir ders tespit edilmemiştir.

Tablo 1: Türkçe öğretmenliğilisans programıolan üniversiteler (öğrencisiolan)

\begin{tabular}{|l|l|}
\hline Abant İzzet Baysal Üniversitesi & İnönü Üniversitesi \\
\hline Adıyaman Üniversitesi & İstanbul Üniversitesi \\
\hline Afyon Kocatepe Üniversitesi & Kafkas Üniversitesi \\
\hline Ağrı İbrahim Çeçen Üniversitesi & Karadeniz Teknik Üniversitesi \\
\hline Ahi Evran Üniversitesi & Kastamonu Üniversitesi \\
\hline Akdeniz Üniversitesi & Kilis 7 Aralık Üniversitesi \\
\hline Aksaray Üniversitesi & Kırıkkale Üniversitesi \\
\hline Amasya Üniversitesi & Kocaeli Üniversitesi \\
\hline Artvin Çoruh Üniversitesi & Marmara Üniversitesi \\
\hline Atatürk Üniversitesi & Mehmet Akif Ersoy Üniversitesi \\
\hline Balıkesir Üniversitesi & Mersin Üniversitesi \\
\hline Bartın Üniversitesi & Muğla Sıtkı Koçman Üniversitesi \\
\hline Bayburt Üniversitesi & Muş Alparslan Üniversitesi \\
\hline Bülent Ecevit Üniversitesi & Mustafa Kemal Üniversitesi \\
\hline Çanakkale Onsekiz Mart Üniversitesi & Necmettin ErbakanÜniversitesi (Ereğli Eğitim Fak.) \\
\hline Celâl Bayar Üniversitesi & Necmettin Erbakan Üniversitesi \\
\hline Çukurova Üniversitesi & Nevşehir Hacı Bektaş Veli Üniversitesi \\
\hline Cumhuriyet Üniversitesi & Niğde Üniversitesi \\
\hline Dicle Üniversitesi & Ondokuz Mayıs Üniversitesi \\
\hline Dokuz Eylül Üniversitesi & Pamukkale Üniversitesi \\
\hline Dumlupınar Üniversitesi & Recep Tayyip Erdoğan Üniversitesi \\
\hline Düzce Üniversitesi & Sakarya Üniversitesi \\
\hline Ege Üniversitesi & Siirt Üniversitesi \\
\hline Erciyes Üniversitesi & Sinop Üniversitesi \\
\hline Erzincan Üniversitesi & Trakya Üniversitesi \\
\hline Fırat Üniversitesi & Uludağ Üniversitesi \\
\hline Gazi Üniversitesi & Uşak Üniversitesi \\
\hline Gaziantep Üniversitesi & Yıldız teknik Üniversitesi \\
\hline Gaziantep Üniversitesi (Nizip Eğitim Fak.) & Yüzüncü Yıl Üniversitesi \\
\hline Gaziosmanpaşa Üniversitesi & Giresun Üniversitesi \\
\hline Hacettepe Üniversitesi & \\
\hline
\end{tabular}


Gazi Üniversitesi Gazi Eğitim Fakültesi Sosyal Bilimlerve Türkçe Eğitimi Bölümü, Türkçe Eğitimi Ana Bilim Dalının ders programında bu ders 8. yarıyılda seçmeli olarak ve "Yurt Dışındaki Türk Çocuklarına Türkçe Öğretimi" adı altında verilmektedir. Dersin öğrenme çıktıları şu şekildedir:

"iki dillilik ve çok kültürlülük kavramlarını tanımlar.

İki dillilerin kültür problemleri hakkında bilgi sahibi olur ve onlara çözümler üretir.

İki dillilerin dil problemleri hakkında bilgi sahibi olur ve onlara çözümler üretir.

Yurt dışında yaşayan Türk çocuklarına Türkiye Türkçesi öğretiminde kullanılan metotları bilir.

Yurt dışında yaşayan Türk çocuklarına Türkiye Türkçesinin öğretim yöntem ve tekniklerinin nasıl uygulanacağını kavrar." (http://gbp.gazi.edu.tr/E.T. 26.08.2016)

Yapılan incelemelerde Türkiye'de iki dilli Türk çocuklarına Türkçe öğretimi alanında öğretmen yetiştiren bir lisans programı bulunmamaktadır. Aynı şekilde Türkçe eğitimi, öğretimi alanına doğrudan öğretmen yetiştiren başka lisans programı mevcut değildir (yabacı dil olarak Türkçe öğretmenliği, Türk soylulara Türkçe öğretmenliği gibi).

Türkçe eğitimi, öğretimi alanında uzman yetiştiren yüksek lisans programları nelerdir? Bu yüksek lisans programları içinde iki dilli Türk çocuklarına Türkçe öğretimi alanında uzman yetiştiren yüksek lisans programı bulunmakta mıdır? Varsa programın içeriği nedir?

109 devlet üniversitesinde 9657 yüksek lisans (istatistik.yok.gov.tr/ E.T. 20.05.2016) programı bulunmaktadır. Bu programlar içinde iki dilli Türk çocuklarına Türkçe öğretimi alanında Gazi Üniversitesi Eğitim Bilimleri Enstitüsü Türkçe Eğitimi Ana Bilim Dalı bünyesinde açılmış olan Yurt Dışındaki Türk Çocuklarına Türkçe Öğretimi Bilim Dalıyükseklisans programı dışında bir program tespit edilmemiştir.

Programın amacı "Yurt dışında yaşayan Türk çocuklarının Türk dilini ve kültürünü tanımalarında, benimsemelerinde, geliştirmelerinde, millîduygularını pekiştirmelerinde ve yaşadıkları ülkeye uyum sağlayarak etkili toplumsal ilişkiler içine girmelerinde onlara rehberlik edecek nitelikli elemanlar yetiştirmeyi hedeflemektedir."(http://gbp.gazi.edu.tr/ E.T. 24.08.2016) şeklinde ifade edilmektedir. Programda Seminer, Uzmanlık Alan Dersi, Tez Dönemi dersleri hariç on bir ders bulunmaktadır. Bu dersler aşağıdaki tabloda gösterilmiştir (http://gbp.gazi.edu.tr/ E.T. 24.08.2016). 
ìki Dilli Türk Çocuklarına Türkçe Öğretiminde Öğretmen Yetiştirme Sorunu Ve Üniversitelerdeki Mevcut Durumun Değerlendirilmesi

Tablo 2: Yurt dışındaki Türk çocuklarına Türkçe öğretimi yüksek lisans programı dersleri

\begin{tabular}{|l|}
\hline Çağdaş Türkçe Dil Bil gisi Öğretimi \\
\hline Türk Kültürü ve Uygarlığı \\
\hline Yurt Dışındaki Türk Çocuklarına Dinleme-Okuma Öğretimi \\
\hline Yurt Dışındaki Türk Çocuklarına Konuşma-Yazma Öğretimi \\
\hline İki Dilli Ortamda Ana Dili Olarak Türkçe Öğretiminin Temel Sorunları \\
\hline $\begin{array}{l}\text { Yurt Dışındaki Türk Çocuklarına Türkçe Öğretimi Kaynakça } \\
\text { Incelemeleri }\end{array}$ \\
\hline Türkçe Öğretimi Tarihi \\
\hline Kültürler Arası Illetişim \\
\hline KlasikTürk Edebiyatı Eğitimi \\
\hline Türkçe Öğretiminde Materyal Tasarımıve Eleştirisi \\
\hline Dil Becerilerinin Geliştirilmesi \\
\hline
\end{tabular}

Karşılaştırma yapabilmek ve konu ile ilgili durum hakkında fikir sahibi olabil mek için lisansüstü programlarında Türkçe eğitimi/öğretimi ile ilgili hangi programların olduğuna da bakmak gerekir. Bu amaçla yapılan taramalarda 32 Türkçe öğretimi/eğitimi/öğretmenliği yüksek lisans programı tespit edilmiştir. Bu programların bulunduğu üniversiteler Tablo 3'te gösterilmiştir.

Tablo 3: Türkçe öğretimi alanında yüksek lisans programı olan üniversiteler

\begin{tabular}{|l|l|l|}
\hline $\begin{array}{l}\text { Abant İzzet Baysal } \\
\text { Üniversitesi }\end{array}$ & $\begin{array}{l}\text { Necmettin Erbakan } \\
\text { Üniversitesi }\end{array}$ & Fırat Üniversitesi \\
\hline Ankara Üniversitesi & $\begin{array}{l}\text { Ondokuz Mayıs } \\
\text { Üniversitesi }\end{array}$ & Gaziantep Üniversitesi \\
\hline Atatürk Üniversitesi & Pamukkale Üniversitesi & $\begin{array}{l}\text { Gaziosmanpaşa } \\
\text { Üniversitesi }\end{array}$ \\
\hline Balıkesir Üniversitesi & Sakarya Üniversitesi & Giresun Üniversitesi \\
\hline $\begin{array}{l}\text { Bülent Ecevit } \\
\text { Üniversitesi }\end{array}$ & Siirt Üniversitesi & İstanbul Üniversitesi \\
\hline $\begin{array}{l}\text { Çanakkale Onsekiz Mart } \\
\text { Universitesi }\end{array}$ & Uludağ Üniversitesi & İstanbul Üniversitesi \\
\hline Dicle Üniversitesi & Uşak Üniversitesi & $\begin{array}{l}\text { Karadeniz Teknik } \\
\text { Üniversitesi }\end{array}$ \\
\hline Dokuz Eylül Üniversitesi & Yüzüncü Yıl Üniversitesi & Gazi Üniversitesi \\
\hline Dumlupınar Üniversitesi & Kilis 7 Arlık Üniversitesi & Kırıkale Üniversitesi \\
\hline Erzincan Üniversitesi & Marmara Üniversitesi & $\begin{array}{l}\text { Muğla Sıtkı Koçman } \\
\text { Üniversitesi }\end{array}$ \\
\hline Mersin Üniversitesi & $\begin{array}{l}\text { Afyon Kocatepe } \\
\text { Üniversitesi }\end{array}$ & \\
\hline
\end{tabular}

Son yıllarda yabancı dil olarak Türkçenin öğretimi alanında önemli gelişmeler kaydedilmiştir. Yabancı dil olarak Türkçenin öğretimi alanında açılan yüksek lisans programları da bu gelişmeler içinde değerlendirilebilir. Yapılan taramalar sonucunda yabancı dil olarak Türkçenin öğretimi alanında 8 yüksek lisans programı tespit edilmiştir. Bu programların bulunduğu üniversiteler Tablo 4'te gösterilmiştir. 
Tablo 4: Türkçenin yabancı dil olarak öğretimi alanında yüksek lisans programı olan üniversiteler

\begin{tabular}{|l|l|}
\hline $\begin{array}{l}\text { Çanakkale Onsekiz Mart } \\
\text { Universitesi }\end{array}$ & Ankara Üniversitesi \\
\hline Dokuz Eylül Üniversitesi & İstanbul Üniversitesi \\
\hline Sakarya Üniversitesi & Hacettepe Üniversitesi \\
\hline Gazi Üniversitesi & $\begin{array}{l}\text { Nevşehir Hacı Bektaş Veli } \\
\text { Üniversitesi }\end{array}$ \\
\hline
\end{tabular}

Türkçe eğitimi, öğretimi alanında uzman yetiştiren doktora programları nelerdir? Bu doktora programları içinde iki dilli Türk çocuklarına Türkçe öğretimi alanında uzman yetiştiren doktora programı bulunmakta mıdır? Varsa programın içeriği nedir?

109 devlet üniversitesinde 4666 doktora (istatistik.yok.gov.tr/ E.T. 20.05.2016) programı bulunmaktadır. Bu programların içinde iki dilli Türk çocuklarına Türkçe öğretimine yönelik bir doktora programına rastlanmamıştır. Türkçe öğretimi alanında ise 19 doktora programı tespit edilebilmiştir.

Tablo 5: Türkçenin öğretimi alanında doktora programı olan üniversiteler

\begin{tabular}{|l|l|}
\hline Ankara Üniversitesi & İstanbul Üniversitesi \\
\hline Atatürk Üniversitesi & Marmara Üniversitesi \\
\hline Bolu Abant İzzet Baysal Üniversitesi & Mersin Üniversitesi \\
\hline Çanakkale Onsekiz Mart Üniversitesi & Muğla Sıtkı Koçman Üniversitesi \\
\hline Dokuz Eylül Üniversitesi & Mustafa Kemal Üniversitesi \\
\hline Dumlupınar Üniversitesi & Necmettin Erbakan Üniversitesi \\
\hline Erciyes Üniversitesi & Sakarya Üniversitesi \\
\hline Fırat Üniversitesi & Selçuk Üniversitesi \\
\hline Gazi Üniversitesi & Uşak Üniversitesi \\
\hline Innönü Üniversitesi & \\
\hline
\end{tabular}

Yabancı dil olarak Türkçe öğretimi doktora programının da yüksek lisans programına paralel olarak son yıllarda sayısı giderek artmaktadır. Yabancı dil olarak Türkçe öğretimi alanında 4 doktora programı tespit edilmiştir. Tespit edilen doktora programlarının hangi üniversitelerde ol duğu aşağıdaki tabloda gösterilmiştir.

Tablo 6: Türkçenin yabancı dil olarak öğretimi alanında doktora programı olan üniversiteler

\begin{tabular}{|l|}
\hline Ankara Üniversitesi \\
\hline Dokuz Eylül Üniversitesi \\
\hline Gazi Üniversitesi \\
\hline Hacettepe Üniversitesi \\
\hline İstanbul Üniversitesi \\
\hline
\end{tabular}


iki Dilli Türk Çocuklarına Türkçe Öğretiminde Öğretmen Yetiştirme Sorunu Ve Üniversitelerdeki Mevcut Durumun Değerlendirilmesi

\section{Sonuç}

Türkiye'de iki dilli Türk çocuklarına Türkçe öğretimi alanında öğretmen yetiştiren bir lisans programı bulunmamaktadır. Lisans programının olmayışı en azından Türkçe öğretmenliği lisans programında iki dilli Türk çocuklarına Türkçe öğretimi alanında derslerin veriliyor olduğunu düşündürmüş, ancak devlet üniversitelerindeki 63 Türkçe Öğretmenliği lisans programında Gazi Üniversitesi Türkçe Öğretmenliği lisans programı hariç hiçbir programda böyle bir ders tespit edilememiştir. Yüksek lisans programları incelendiğinde Gazi Üniversitesi Eğitim Bilimleri Enstitüsü Türkçe Eğitimi Ana Bilim Dalı bünyesinde açıl mış olan Yurt Dışındaki Türk Çocuklarına Türkçe Öğretimi Yüksek Lisans Programı dışında herhangi bir program bulunmamaktadır. İki dilli Türk çocuklarına Türkçe öğretimi alanında herhangi bir doktora programı da tespit edilememiştir.

Durum böyle olunca alan bilgisi olmayan yılda ortalama 400 öğretmen yurt dışındaki Türk çocuklarına Türkçe öğretmek üzere görevlendirilmektedir. Görevlendirilen öğretmenlerin alan uzmanlığına sahip olmamaları, ayrıca bu öğretmenlerin Müzik, Din Kültürü ve Ahlak Bilgisi, Sosyal Bilgiler, Rehberlik, İngilizce, Fransızca, Almanca, Türkçe, Türk Dili ve Edebiyatı gibi çok geniş bir branş çeşitliliği içerisinden atanmaları çok ilginç ve gariptir. Bir dersi her branştan öğretmen verebiliyorsa neden farklı branşlarda öğretmen yetiştiriliyor? Başka bir bakış açısıyla, Türkçe öğretmenleri Müzik derslerini; Din Kültürü ve Ahlak Bilgisi öğretmeleri de İngilizce derslerini verebilir mi? Türkçe derslerini Türkçe öğretmenleri, müzik derslerini Müzik öğretmenleri vermelidir. Her branşın kendine özgü alan bilgisi, mesleki yeterliliği vardır. Yurt dışında yaşayan Türk çocuklarına yapılacak ana dili eğitiminin Türkiye'deki ana dili eğitiminden farklı olması gerektiği, aynı şekilde Türkiye'deki öğrenciler için hazırlanan ders materyallerinin doğrudan iki dilli Türk çocuklarına kullanılamayacağı unutul mamalıdır. Bu sebeple "iki dilli Türk çocuklarına Türkçe öğretimi" alan uzmanlığı, alana özgü mesleki yeterlilik gerektirir (Buradaki eleştiri öğretmen yetiştirme noktasındadır. Ataması yapılmış öğretmenlerimiz üzerinden bir değerlendirme değildir.)

Yurt dışında yaşayan Türk çocuklarına Türkçe öğretimi her branştan öğretmenin göç yolda düzülür mantığıyla yapacağı bir iş değildir. Yurt dışına görevlendirilecek öğretmenlerin yetiştirilmesi için ciddi adımlar atılması gerekirken 2016 atamalarında Mesleki Yeterlilik Sınavının yapılmaması, atanacak öğretmenlerin Temsil Yeteneği Mülakatı ile alınması da endişe vericidir.

Öncelikle ileriye yönelik olarak iki dilli Türk çocuklarına Türkçe öğretimi lisans programının açıl ması için (istihdam, öğretim elemanı kadrosu vb. değerlendirmeleri yapılarak) gerekli düzenlemeler yapılmalıdır. Türkçe öğretmenliği bölümlerinde iki dilli Türk çocuklarına Türkçe öğretimine yönelik dersler konmalı, ayrıca iki dilli Türk çocuklarına Türkçe öğretimi yüksek lisans programlarının sayısı arttırımalı, yüksek lisans programlarını tamamlayacak doktora programları açılmalıdır. Gazi 
Üniversitesi Eğitim Bilimleri Enstitüsü Türkçe Eğitimi Ana Bilim Dalı bünyesinde açılmış olan Yurt Dışındaki Türk Çocuklarına Türkçe Öğretimi Yüksek Lisans Programı içeriğine bakıl dığında Avrupa eğitim sistemi, iki dilli eğitim (kuram ve uygulama), iki dilli eğitim modelleri gibi derslerin eksikliğinden söz edilebilir. Bu türden derslerin programda olması yetişecek uzmanların daha yetkin ve alana hâkim olmasına katkı sağlayacaktır.

Türkçe ve Türk kültürü dersi öğretmen atamalarında farklı branştan atanma yapılmamalıdır. Türkçe öğretmenliği atanmaya esas olmalıdır. Ancak bunun öncesinde Türkçe öğretmenlerinin lisans programlarına alanla ilgili dersler konulmalıdır. İki dilli Türk çocuklarına Türkçe öğretimi alanında lisansüstü eğitim almış ancak öğretmen olarak ataması yapılmamış ya da atanmış ama 5 yıllık mesleki tecrübeye sahip olmayanlar için yeni düzenlemeler yapılmalıdır.

Yabancı dil olarak Türkçe öğretimi, lisans programlarının hemen hepsinde ders olarak okutulmaktadır. Bunun yanı sıra yabancı dil olarak Türkçe öğretiminin yüksek lisans ve doktora programları da bulunmaktadır. Lisans, lisansüstü eğitimle yabancı dil olarak Türkçe öğretimi bilgi ve yeterliliğine sahip olamayanlar bu açıklarını sertifika programları ile kapatabilme imkânına da sahiptir. Birçok üniversite bünyesinde yabancı dil olarak Türkçe öğretimi sertifika programları açımaktadır. Yabancı dil olarak Türkçe öğretiminde olduğu gibi iki dilli Türk çocuklarına Türkçe öğretimi alanında da aynı tablonun ortaya çıkması gerekir. Bu sebeple, Yurt Dışındaki/iki dilli Türk Çocuklarına Türkçe Öğretimi Lisans Programı, Yurt Dışındaki Türk Çocuklarına Türkçe Öğretimi Tezli Yüksek Lisans Programı, Yurt Dışındaki Türk Çocuklarına Türkçe Öğretimi Tezsiz Yüksek Lisans Programı, Yurt Dışındaki Türk Çocuklarına Türkçe Öğretimi Sertifika Programı, Yurt Dışındaki Türk Çocuklarına Türkçe Öğretimi Doktora Programları açılmalıdır.

\section{Kaynaklar}

Abalı, Ü. (2000). Almanya'daki Türk Eğitimcileri İ̧̧in Öğretmen El Kitabı. Ankara: Milli Eğitim Bakanlığı Yayınları. Aydoğan, i. (2008). Yurt Dışına Görevlendirilen Öğretmenlerin Sorunları. I. Uluslararası Avrupalı Türkler Kongresi "Eğitim ve Kültür", Cilt I, 220-235.

Aytemiz, A. (2000). Almanya'da Türkçe. Avrupa'da Yaşayan Türk Çocuklarının Ana Dili Sorunları Toplantısı. Ankara: Türk Dil Kurumu Yayınları.

Belet, ş. (2009). İki Dilli Türk Öğrencilerin Ana Dili Türkçeyi Öğrenme Durumlarına İlişkin Öğrenci, Veli Ve Öğretmen Görüşleri (Fjell illköğretim Okulu Örneği, Norveç). Selçuk Üniversitesi Sosyal Bilimler Enstitüsü Dergisi, 21, 71-85.

Cengiz, K. ve Türk, H. (2009). Hatay'da Iki Dillilik ve İki Dillilikten Kaynaklanan Dil Karışması. Mustafa Kemal Üniversitesi Sosyal Bilimler Enstitüsü Dergisi, 6 (12), 190-208.

Cummins, J. (2001). Bilingual Children's Mother Tongue: Why is it important For Education?. Sprogforum, February, 7 ( 19). 15-29.

Demir, N. (2016). Bir Sivil Toplum Örgütü Olarak "Alman Türkleri Birliği”. Zeitschrift für die Welt der Türken / Journal of World of Turks [ZfWT], 8(1), 7-23. 
ìki Dilli Türk Çocuklarına Türkçe Öğretiminde Öğretmen Yetiştirme Sorunu Ve Üniversitelerdeki Mevcut Durumun Değerlendirilmesi

Demirbaş, H. (2014). Eğitim-Kültür Açısından Avrupa'daki Türk Çocukları - Sorunlar ve Çözümler. Ankara: Nobel Yayın.

Dış İlişkiler Genel Müdürlüğü (DiGM) (2015). Yurt Dışında Görevlendirilecek Öğretmenlerin Mesleki Yeterlilik Sınavı ve Temsil Yeteneği Mülakatı Başvuru Kılavuzu. Ankara.

Ince, B. (2011). Yurt Dışındaki Türk Çocuklarının Anadilleri Türkçe’de Yaşadıkları Anlatım Sorunları: Fransa Örneği. İstanbul Üniversitesi, Sosyal Bilimler Enstitüsü Yayımlanmamış Doktora Tezi, İstanbul.

Karasar, N. (2008). Bilimsel Araştırma Yöntemi: Kavramlar, Illkeler, Teknikleri, (18. Baskı), Ankara: Nobel

Koçak, M. (2012). Al manya'da Yaşayan Türklerin Türkçe Dil Becerileri Üzerine Bir İncel eme. Zeitschrift für die Welt der Türken / Journal of World of Turks [ZfWT], 4 (1), 303-313.

Sarı, M. (2001). iki Dilli Çocukların Çözümleme Yöntemiyle Okuma-Yazma Öğrenirken Karşılaştıkları Güçlükler. Çukurova Üniversitesi Eğitim Bilimleri Enstitüsü, Yayımlanmamış Yüksek Lisans Tezi, Adana.

Şen, Ü. (2011). Belçika'da Yaşayan Türk Çocuklarının Türkçeye Yönelik Tutumları ve Yazma Becerileri, Gazi Üniversitesi Eğitim Bilimleri Enstitüsü Yayımlanmamış Doktora Tezi, Ankara.

Yıldız, C. (2012). Yurt Dışında Yaşayan Türk Çocuklarına Türkçe Öğretimi (Almanya örneği). Yurtdışı Türkler ve Akraba Toplulukları Başkanlığı: Ankara.

Yıldız, M., Öztürk, S. (2013). Almanya'da İlkokulda Öğrenim Gören Türk Çocuklarının Yazma Becerileri Üzerine Bir Incel eme: Stuttgart örneği. Zeitschrift für die Welt der Türken Journal of World of Turks ZfWT, 2 (5), 139155. 